\section{Pluralismo, neocorporativismo e o sindicalismo dos agricultores familiares no Brasil}

Recebido: 26.11 .16 Aprovado: 17.07 .17
Everton Lazzaretti Picolotto*

Resumo: O objetivo do artigo é analisar o processo de formação da Federação dos Trabalhadores na Agricultura Familiar (Fetraf) na área de atuação tradicional da Confederação Nacional dos Trabalhadores na Agricultura (Contag) e a situação de pluralidade sindical gerada. O sindicalismo rural brasileiro foi criado na década de 1960 e, desde a sua formação, conviveu com uma tensão entre os diversos grupos sociais que formaram a categoria trabalhador rural. Nessa categoria foram enquadradas as categorias que viviam do trabalho, tais como assalariados, pequenos proprietários, posseiros, sem-terra. Desde o processo de redemocratização, este sistema de representação sindical foi questionado com a formação de diversos novos atores no campo. Porém, foi com a criação da Fetraf, em 2001, como órgão específico dos agricultores familiares, que passou a se formar uma situação de pluralismo sindical no campo. Esta situação tem gerado uma forte concorrência por legitimidade e por bases sindicais.

Palavras-chave: sindicalismo, pluralismo sindical, agricultura familiar, Fetraf.

\title{
Introdução
}

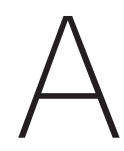

formação de uma organização sindical de agricultores familiares por um setor da Central Única dos Trabalhadores (CUT), no início da década de 2000, tem provocado fortes disputas no campo da representação sindical dos trabalhadores rurais nas últimas décadas. A Confederação Nacional dos TrabaIhadores na Agricultura (Contag) sempre teve, desde a sua fundação, na década de 1960, o monopólio da representação formal dos trabalhadores rurais. No entanto, desde a formação da Federação dos Trabalhadores na Agricultura Familiar (Fetraf) em 2001, por um setor cutista, a confederação estabelecida tem enfrentado concorrência pela representação de uma parcela dos trabalhadores rurais, os agricultores familiares, configurando-se, assim, uma situação de pluralidade no campo brasileiro.

O objetivo deste artigo é analisar o processo de formação de um novo ator sindical (Fetraf) no campo de atuação tradicional da Contag (em especial no sul do país) e a confrontação entre as perspectivas corporativista e pluralista no âmbito do sindicalismo dos trabalhadores rurais. O artigo resulta da tese de doutorado do autor

\author{
* Doutor em \\ ciências sociais \\ pela Universidade \\ Federal Rural do Rio \\ de Janeiro (CPDA) \\ UFRRJ), professor \\ do Departamento \\ de Ciências Sociais \\ e dos Programas de \\ Pós-Graduação em \\ Ciências Sociais e \\ Extensão Rural da \\ Universidade Federal \\ de Santa Maria \\ (UFSM), Santa Maria \\ (RS), Brasil. <everton \\ picolotto@ufsm.br>.
}


1. Este artigo traz resultados parciais do projeto "A formação do sindicalismo da agricultura familiar no Brasil e a pluralidade sindical no campo", Edital de Ciências Humanas e Sociais - MCTI/ $\mathrm{CNPq} / \mathrm{MEC} / \mathrm{CPES}, \mathrm{n}$ 22/2014.
(Picolotto, 2011) e de investimentos de pesquisa posteriores com financiamento do $\mathrm{CNPq}^{1}$, a partir da análise de documentos das organizações sindicais e de entrevistas com suas lideranças e assessores.

\section{Gênese do sindicalismo dos trabalhadores rurais}

O sindicalismo brasileiro foi estruturado na década de 1930 pelo governo Vargas, seguindo uma forma corporativista de conceber as relações Estado-sociedade, corporativismo que Schmitter (1974) chamou de "corporativismo estatal ou autoritário", no qual as representações dos grandes interesses sociais estariam subordinadas à "autoridade estatal, quando não são criadas por ela (conforme complementam Araújo \& Tápias, 1991: 10). Esse corporativismo é monista, busca a unidade dos múltiplos interesses em um único corpo de representação e um dos seus traços característicos é a forte identificação entre Estado e sociedade, com afluências para a concentração do poder do primeiro. O'Donnell (1975) acrescenta que as influências do corporativismo na América Latina não se deram apenas na formação das estruturas de representação e intermediação da relação Estado-sociedade, mas também forneceram base para as estruturas de dominação. Tal perspectiva orienta o Estado a assumir um caráter "bifronte" com relação às classes sociais: um viés "estatizante", que consiste na subordinação das organizações da sociedade civil e cujo conteúdo principal é o controle sobre as classes populares (especialmente dos sindicatos de trabalhadores); e um viés "privatista", que consiste na abertura de áreas institucionais do Estado à representação dos interesses das classes e dos setores dominantes.

A formação da estrutura sindical brasileira observa esta lógica corporativista com forte controle estatal das organizações sindicais de trabalhadores e a transferência de competências e recursos públicos para as organizações patronais, a exemplo do "sistema S" (Senai, Senac, Senar etc.). Para este trabalho, interessa observar as influências deste modelo na formação do sindicalismo de trabalhadores rurais. Uma delas diz respeito à inserção dos trabalhadores rurais no campo político que se deu sob a tutela do Estado frente às organizações sindicais. Tal tutela foi estabelecida pela chamada investidura sindical, que significou a necessidade de reconhecimento prévio do sindicato pelo Estado, o qual se dava através da carta sindical. Ou seja, era o Estado que outorgava às entidades sindicais a representatividade de um determinado segmento de trabalhadores e o poder de negociação com os órgãos patronais. Além disso, o Ministério do Trabalho tinha forte controle sobre a vida sindical, seja na regulação das eleições, da investidura de diretorias, do poder de intervenção, da fiscalização das ações e das finanças. A segunda característica desse sindicalismo diz respeito à unicidade sindical, o que significava que só poderia haver uma 
organização sindical, em qualquer grau, representativa de categoria profissional ou econômica, na mesma base territorial. Por fim, a terceira característica refere-se às contribuições sindicais obrigatórias estabelecidas por lei: imposto sindical e taxa assistencial. Tais contribuições constituíram uma espécie de poder tributário concedido pelo Estado aos sindicatos, que leva os sindicatos a dependerem do próprio Estado, e não dos trabalhadores de sua base, para se financiarem (Vianna, 1976; Pinto, 1979; Boito Jr., 1991).

O sindicalismo rural brasileiro for regulamentado na década de 1960, seguindo esse mesmo modelo sindical. Foi estruturado na forma de uma representação patronal ou empresarial, de uma parte, e uma de trabalhadores, de outra. O Decreto-Lei n.. 1.166, de 1971, estabeleceu como critérios fundamentais para o enquadramento na categoria "trabalhador rural" a condição de assalariamento rural, ou, quando agricultor, explorar com suas famílias áreas de terra de até um módulo rural²; se explorar áreas acima desta medida seria considerado "empresário ou empregador rural", mesmo sem empregados ${ }^{3}$. Cada uma dessas categorias teve sua estrutura sindical reconhecida e regulada pelo Estado. A Confederação Nacional da Agricultura (CNA) organizou a representação patronal ou empresarial. O sindicalismo dos trabalhadores rurais foi organizado na forma de Sindicatos dos Trabalhadores Rurais (STRs) em âmbito municipal; nas Federações de Trabalhadores na Agricultura (Fetags) nos estados; e na Confederação Nacional dos Trabalhadores na Agricultura (Contag), órgão sindical superior no plano nacional. Nessa estrutura, toda a diversidade de grupos sociais e de situações de trabalho rural foi enquadrada na categoria trabalhador rural, fossem eles assalariados, pequenos proprietários, arrendatários, posseiros, entre outros (Palmeira, 1985; Medeiros, 1989; 2010; Novaes, 1997).

Nas disputas políticas que conformaram a gênese deste sindicalismo, a opção do grupo que assumiu, em 1968, a direção da Contag, após um período de intervenção do regime militar, foi a de realizar um esforço político para garantir a unificação dessa diversidade contra tendências que se esboçavam nas direções quer de enquadramento dos pequenos produtores nos sindicatos patronais, ligados à CNA, quer de formação de um sindicalismo próprio dos pequenos produtores (Medeiros, 2010; Palmeira, 1985). A possibilidade de formar uma terceira faixa de enquadramento sindical, para os pequenos proprietários, aparecia nas articulações dos sindicalistas do sul do país, que não se sentiam confortáveis na Contag, pois esta sofria a hegemonia de assalariados, parceiros e posseiros; lutavam também pela ampliação do enquadramento sindical dos agricultores para além das medidas de um módulo rural, o que era visto com restrições por sindicalistas de outras regiões (Picolotto, 2014a). Mesmo com estas diferenças, a Contag teve sucesso em manter todos os grupos que viviam do trabalho unidos na categoria trabalhador rural. Como elucida
2. O módulo rural é definido pelo Estatuto da Terra (Lei n.․ 4.504, de 1964) e corresponde à área mínima necessária a uma exploração familiar rural para que sua exploração seja economicamente viável.

3. A Lei n. .9 .701 de 1998, redefiniu o enquadramento para os agricultores em até dois módulos rurais para serem considerados trabalhadores rurais. 
Francisco Urbano (dirigente da Fetag-RN nas décadas de 1960-1970 e da Contag nas de 1970-1990), para isso, foi necessário definir um programa unificador:

\begin{abstract}
O pessoal do Sul estava cobrando assim: "vocês só falam em reforma agrária, direito trabalhista e previdenciário. Ok, beleza. Mas nós somos pequenos proprietários, queremos política agrícola". Isso virou um debate muito complicado... Bom, [o objetivo era] conseguir manter todo mundo junto, foi aí que, em 1968, ao retomar a Contag da mão da ditadura, passamos uma semana no Rio de Janeiro, lá em Petrópolis, discutindo que movimento sindical queríamos, que Contag a gente queria. E lá saiu um grande programa chamado Plano de Integração Nacional. Esse Plano de Integração Nacional era assim: temos que ter políticas para todos os grupos que nós representamos. Você tinha o pequeno agricultor, o meeiro, o arrendatário, o assalariado, o extrativista, o ribeirinho na Região Amazônica. Então saiu um programa que trabalhava na luta pela política agrícola, a luta pela reforma agrária, pelos direitos trabalhistas e pelos direitos previdenciários (Urbano, entrevista ao autor, 2016).
\end{abstract}

4. Em outros estados brasileiros - e mesmo na Contag -, a relação com o Estado e com setores da Igreja se deu de forma diferenciada. Para compreender estas dinâmicas em outros estados e no âmbito nacional, ver Pinto (1979), Medeiros (1989), Palmeira (1985), Paiva (1985), Novaes (1997).
Na Região Sul, com o regime militar, as Fetags foram influenciadas por organismos católicos (como a Frente Agrária Gaúcha e a Frente Agrária Paranaense), criados para conduzir os trabalhadores rurais de forma ordeira, respeitando a legislação e em colaboração com o Estado, na busca de uma melhor inserção econômica e o avanço das condições de vida no campo ${ }^{4}$. Nessa perspectiva, as federações tiveram papel importante no processo de modernização da agricultura entre os pequenos produtores e na prestação de serviços assistenciais de saúde e previdência social aos trabalhadores rurais, mantendo uma postura de colaboração com os órgãos do Estado (Maduro, 1990; Heller da Silva, 2006; Picolotto, 2011). Esta postura passaria a ser fortemente criticada a partir do final de década de 1970, momento em que se formavam novos atores a questionarem as consequências das políticas de modernização agrícola, da concentração de terras, do modelo energético e da falta de direitos.

Apoiado pelos setores progressistas das Igrejas Católica e Luterana (ligadas à Teologia da Libertação), foi fundado na região, na década de 1980, o sindicalismo rural identificado com a Confederação Única do Trabalho (CUT), com o Movimento dos Trabalhadores Rurais Sem-Terra (MST), o Movimento dos Atingidos por Barragens (MAB), o Movimento das Mulheres Trabalhadoras Rurais (MMTR), entre outros. Juntos, estes atores, que tinham forte expressão nos três estados do Sul, deram início ao embrião de uma organização interestadual com a formação da Articulação Sindical Sul, em 1984. Tratava-se de uma articulação de oposição ao sindicalismo da Contag e às suas federações nos estados. A partir do final de 1988, com o bene- 
plácito da CUT, esta proposta organizativa ganharia corpo com a criação do Departamento Nacional dos Trabalhadores Rurais (DNTR) e dos Departamentos Estaduais (DETRs) da CUT. Tratava-se de uma iniciativa ousada para a formação de uma estrutura sindical paralela à Contag, uma afronta direta à legislação sindical vigente.

Com estes novos atores, conformava-se um "campo de forças" (Bourdieu, 2005) no âmbito da representação política com rebatimentos no sindicalismo. Enquanto o sistema Contag defendia a unidade corporativa da categoria trabalhador rural, por meio da manutenção da unicidade sindical e de seu monopólio na representação de todos os trabalhadores do campo, de outro lado, o sindicalismo rural ligado à CUT propunha autonomia e liberdade sindical, qual seja, a possibilidade de formar novos sindicatos autônomos, mais adequados à organização das lutas de categorias sociais específicas no campo. Seja entre os assalariados rurais, seja entre os pequenos produtores e os sem-terra, defendia uma diferenciação das estruturas. A postura da CUT baseava-se em um ideário influenciado pelas experiências pluralistas de vertente socialista e anarquista de origem europeia e norte-americanas (Ladosky, 2014; Goldin, 2013; Ricci, 2013). Na concepção pluralista convivem

vários grupos ou centros de poder, mesmo que em conflito entre si, aos quais é atribuída a função de limitar, controlar e contrastar, até o ponto de eliminar o centro do poder dominante, historicamente identificado com o Estado (Bobbio, 1998: 928).

Trata-se de uma corrente de pensamento que se opõe à concentração e à unificação do poder e, no campo sindical, se opõe ao monopólio corporativista da estrutura sindical oficial. É favorável à coexistência de organizações sindicais diversas competindo entre si, segundo a lógica de um "campo" ou "mercado" político, no qual os agentes competem por ideias, por interesses e pela representação de bases sociais.

O processo de democratização da sociedade brasileira, ao longo dos anos 1980, e a pressão e as conquistas dos movimentos sociais, na Constituição de 1988, favoreceram o fortalecimento da sociedade civil frente ao Estado, pulverizando os centros de representação e enfraquecendo o jugo corporativista tradicional. Deram base para a formação de uma expressiva pluralização dos movimentos sociais (sejam sindicais ou por fora dos canais sindicais), o que configura diversos centros de representação de interesses; o enfraquecimento da tutela estatal sobre as organizações sindicais; a criação de espaços de negociação entre o Estado e as classes sociais para onde os movimentos sociais, e a CUT em particular, canalizaram não apenas suas demandas, mas também o exercício do controle social sobre o Estado por meio dos diversos conselhos de políticas públicas, câmaras bipartites e tripartites, fóruns de debates, conferências, entre outros (Alves, 2000; Domingues, 2007; Ladosky, 2014). 
5. Tal hibridismo também aparecia no levantamento sobre a influência cutista apresentado no II Congresso do DNTR de 1993: "Houve um crescimento significativo, tanto de sindicatos filiados à CUT, que passaram de 400 [em 1990, quando do I Congresso do DNTR] para 630, como de federações, de uma para três. Foram implantados Departamentos Estaduais em 12 estados (SP, BA, $C E, S E, P I, P B, R O$, $A C, M S, R S, S C$ e $P R)$. Além disso, conseguimos composição em nove federações e na própria Contag. A Federação dos Assalariados Rurais (SP), criada em 1989, filiou-se à CUT. Nos estados de Minas Gerais e Espírito Santo, a representação se dá através do Fórum Cutista, entre federações e sindicatos filiados" (DNTR, 1993a: 5).
Contudo, o fortalecimento da sociedade civil e a pluralização dos grupos e centros de representação não foram traduzidos de forma direta em mudança do estatuto legal do corporativismo sindical na Constituição de 1988. Se, de um lado, a nova Carta estabeleceu que os cidadãos devem ter liberdade de organização política e sindical, de outro, em termos de estrutura sindical, manteve pilares fundamentais do corporativismo, como a unicidade, as contribuições sindicais obrigatórias (similar ao antigo imposto sindical) e o poder normativo da Justiça do Trabalho.

Esta ambiguidade constitucional deu base para novas disputas no sindicalismo dos trabalhadores rurais nos anos seguintes. Enquanto a Contag procurou manter o monopólio da representação oficial dos trabalhadores rurais em geral, o setor rural da CUT buscou construir uma nova estrutura sindical sob seu domínio. Esta última criou o DNTR e suas estruturas estaduais (DETRs) em 1988, a Federação dos Empregados Rurais Assalariado de São Paulo (Feraesp) em 1989 e sindicatos e federações de agricultores familiares na Região Sul nos anos 1990 e 2000.

\section{Encruzilhada sindical: encontro de duas perspectivas}

A postura do sindicalismo rural da CUT era dúbia no início da década de 1990. Ao mesmo tempo em que se propunha a construir o DNTR como organização sindical paralela à Contag, mantinha a tática de conquistar estruturas sindicais existentes e, em muitos locais, os cutistas dirigiam STRs e Fetags (Favareto, 2001). Essa dubiedade é revelada no depoimento de Altemir Tortelli, coordenador do DETR-RS (1991) e secretário-geral do DNTR (1993):

\begin{abstract}
A decisão era assim, nós vamos ficar fora da estrutura das Fetag, nós vamos ficar fora da Contag, nós vamos ganhar os sindicatos da estrutura... e vamos criar os Departamentos. Só que alguns lugares do Brasil, tipo Pará, não tinha nada, não tinha nem Fetag, nem Departamento. A lei só te permitia criar uma Fetag. Em Rondônia, no Tocantins, no Amapá, o nosso pessoal, em vez de criar o Departamento Rural da CUT, que era uma figura não formal, não legal, resolveu criar as federações oficiais. E na Bahia, em Pernambuco, em Minas Gerais os nossos companheiros cutistas... ganharam por dentro as federações... Aí começou a se instalar o conflito "por onde é que se constrói a CUT no campo?" Em 91 passou a ser um movimento híbrido, o discurso era vamos atuar "por dentro" e "por fora" também (Entrevista ao autor, 2010)
\end{abstract}

Antes do V Congresso da Contag, realizado em 1991, instalou-se uma polêmica quanto a participar ou não desse espaço do sindicalismo oficial. Mesmo com fortes 
restrições e a resistência de alguns estados, acabou vencendo a proposta de participação do congresso. Neste ano, a CUT indicou dois nomes para compor a diretoria da Contag. A partir desse momento, o DNTR passava a adotar uma estratégia híbrida de atuar por dentro e por fora da Contag, iniciando um movimento de mudança de rumo do sindicalismo cutista no campo. Essa dubiedade de posições também faz supor que estava em curso um movimento de "contaguização" da CUT. O sistema sindical da Contag atraia para a sua órbita sindicalistas da CUT, fazendo-os secundarizar a perspectiva de construção de uma nova estrutura sindical orgânica no âmbito da CUT.

Esse era um momento em que o sindicalismo cutista atravessava profunda crise quanto ao seu papel - pelas dificuldades de firmar-se como interlocutor perante o Estado e de ampliar sua inserção sindical nacional (Favareto, 2001) -, passando a reavaliar sua posição de organização paralela ao sistema Contag. No espaço do II Congresso do DNTR, em 1993, este debate aflorou. Foram apresentadas tanto posições favoráveis à entrada dos cutistas na Contag, quanto posições que defendiam a criação de uma nova confederação nacional de trabalhadores rurais da CUT (orgânica à Central, a exemplo dos metalúrgicos que, em 1992, havia criado a Confederação Nacional dos Metalúrgicos da CUT). Sem chegar a uma decisão final, o congresso remeteu esse debate para uma Plenária Nacional do DNTR, que seria realizada em agosto de 1993. A plenária tomou a decisão em favor da "participação na estrutura oficial" (DNTR, 1993b) e estabeleceu uma estratégia para filiação da Contag à CUT, entendida como "o resultado do máximo acúmulo político e organizativo possível das forças cutistas na Contag, desde a sua base" (DNTR, 1993b). Em suma, a filiação da Contag deveria ser o resultado de um amplo processo de conquistas de espaços dentro do sindicalismo e, ao mesmo tempo, este ato deveria representar uma transformação do sindicalismo dos trabalhadores rurais para os princípios e projetos cutistas. A construção da unidade dos trabalhadores do campo passava pela conquista da Confederação.

Por parte da Contag, desde 1991, com a realização de seu V Congresso Nacional, levantou-se o debate sobre sua filiação a uma central sindical para unificar o movimento sindical dos trabalhadores rurais (MSTR), tendo-se reconhecido a CUT como a "mais identificada com as lutas imediatas e com as transformações sociais exigidas pela classe trabalhadora" (Contag, 1994: 10). Este debate foi novamente realizado por ocasião do I Congresso Nacional Extraordinário da Contag, em 1994, e uma vez mais, a filiação foi adiada, pois ao mesmo tempo em que se reconhecia um processo de aproximação, de participação dos cutista na estrutura da confederação, de realização de atividades em conjunto (mobilizações, conselhos, comissões etc.), ainda persistiam "resistências profundas de ambos os lados" (Contag, 1994). Nos Anais 
6. Para maiores detalhes sobre a construção do projeto alternativo de desenvolvimento rural, ver Picolotto (2011). do I Congresso Extraordinário ressaltava-se que, por parte da Contag temia-se a "perda da identidade das instâncias do MSTR: STRs, Fetags e Contag através de uma unidade orgânica com a CUT" (Contag, 1994: 10). Por outro lado, avaliava-se que o DNTR mantinha "uma visão não atualizada do MSTR através de argumentos como estrutura oficial ou dependência exclusiva da contribuição sindical" (Contag, 1994: 10), o que dificultava a aproximação. Além disso, a própria existência da estrutura do DNTR era considerada uma afronta à Contag.

A unificação formal do sindicalismo dos trabalhadores rurais foi consolidada com a aprovação da filiação da Contag à CUT durante o IV Congresso, em 1995. Essa unificação mais do que resolver a "crise" em que se encontrava o sindicalismo promoveu o que Favareto (2001: 38) chamou de um "equacionamento dos dilemas dos dois projetos sindicais e que consubstanciavam a crise do sindicalismo rural brasileiro". Os dilemas do DNTR estavam principalmente nas dificuldades que enfrentava para firmar-se como o interlocutor privilegiado perante o Estado e na ampliação de sua influência sindical nacional; e os da Contag referiam-se à dificuldade de promover atualizações em seu projeto sindical, seja em suas bandeiras de luta, seja em sua estrutura organizativa e nas características da ação sindical.

Com este processo de unificação formal do sindicalismo, todo o acúmulo de debates sobre a construção de um projeto alternativo de desenvolvimento rural com base na agricultura familiar, discutido pelos cutistas desde $1993^{6}$, foi incorporado pela Contag. A adesão à ideia de construção do projeto alternativo de desenvolvimento foi vista como a passagem de um sindicalismo reivindicatório, crítico da ação do Estado (marcado fortemente por mobilizações e reivindicações da década de 1980) para um sindicalismo propositivo (que faz mobilizações, mas que tem propostas concretas, um projeto para a agricultura e para o país), com a participação mais ativa em comissões conjuntas com órgãos do Estado, na realização de estudos sobre a agricultura familiar e na definição de políticas públicas para o seu corpo de filiados.

Tratava-se de um momento em que a própria CUT, como central, passava por mudanças em sua forma de relação com o Estado: passava de um sindicalismo autônomo e de confrontação, nos anos de 1980, para uma tática de cooperação conflitiva, privilegiando ações de participação e de negociação com o Estado e o empresariado (Rodrigues, 1995; Alves, 2000). Com a abertura de alguns espaços de participação definidos pela nova Constituição e influenciada por certo ideário "neocorporativista" de inspiração europeia - que atribui "status público" aos grupos sociais organizados, facultando-Ihes espaços de proposição e negociação e, ao mesmo tempo, mantendo certo controle estatal sobre o seu funcionamento e os seus recursos, o 
que tornava cooperativa e previsível a sua relação com o Estado (Offe, 1989) - assumia o seu lugar nas negociações com entidades patronais e setores do Estado, em arenas de decisão, formulação e gestão das políticas públicas em uma clara ruptura com sua trajetória de autonomia e antiestatal da década anterior (Ricci, 2013; Ladosky, 2014; Alves, 2000; Rodrigues, 1995).

Nos esforços para unificar o sindicalismo dos trabalhadores rurais, ocorreram eventos importantes que mostravam o potencial que a união dos atores do campo (DNTR/CUT, Contag, MST, MAB, entre outros) e a nova postura propositiva poderiam ter, tais como: a construção dos Gritos da Terra Brasil (a partir de 1994), como forma de mobilização unificada e massiva de âmbito nacional, com objetivo de propor e negociar políticas com os governos; a participação da CUT e da Contag na Comissão Técnica do Pequeno Produtor do Ministério da Agricultura (1993-1994), com a atribuição de pensar uma "política agrícola diferenciada" para este público; a realização do ambicioso Projeto CUT/Contag de Pesquisa e Formação Sindical (1996-1999), que visou repensar o projeto e a estrutura sindical rural; e a conquista de políticas públicas de apoio à agricultura familiar, como o Programa Nacional de Apoio à Agricultura Familiar (Pronaf), em 1995 (Grisa \& Schneider, 2014; Picolotto, 2014a).

Entretanto, essas novas orientações sindicais não foram unânimes entre os setores cutistas e, nos anos seguintes, causaram desacordos políticos também com antigos aliados, como o MST. Setores cutistas descontentes com a nova perspectiva de um sindicalismo propositivo e com a unificação sindical deram origem a uma dissidência política que formou o Movimento dos Pequenos Agricultores (MPA) no sul país e no estado do Espírito Santo, em 1996. Da mesma forma, o MST que sempre fora um aliado próximo (e que esteve sob o guarda-chuva da CUT), por discordar destas novas perspectivas do sindicalismo passou a organizar, no final da década de 1990, uma nova articulação de atores sociais do campo separada do campo cutista. Desta articulação seria formada a seção brasileira da Via Campesina.

No âmbito sindical, ainda que a unificação na Contag tenha propiciado conquistas importantes, outras propostas cutistas não tiveram a mesma acolhida, provocando divergências nos anos seguintes. Dentre as principais relacionam-se diferentes propostas de mudança na estrutura sindical levantadas pelos cutistas e referendadas nas pesquisas do Projeto CUT/Contag e nas resoluções dos Congressos Nacionais da CUT de 1997 e 2000 - como a flexibilização das formas organização sindical de base e o reconhecimento das organizações diferenciadas (agricultores familiares e assalariados rurais) -, que não foram aceitas nos fóruns da Contag em nome da unicidade. Com a unificação formal do sindicalismo, estas divergências foram levadas para dentro da Contag e precisaram de respostas deste sistema sindical.
7. A seção brasileira da Via Campesina foi formada em 1999, com atuação destacada principalmente do MST e do MPA. Os atores que a compõe passaram a construir a identidade política de camponês no país e tem mantido algumas divergências teóricas e políticas com o uso da identidade da agricultura familiar. Maiores detalhes sobre o MPA, ver Görgen (1998), e sobre a Via Campesina, ver Fernandes (2004) e Vieira (2011). 
8. Os sentidos que a categoria agricultura familiar assume no país são diversos, tanto no debate acadêmico e nas políticas públicas, como nas disputas políticas entre diferentes organizações de representação rurais (incluindo as patronais, como a CNA). Este texto a toma apenas do ponto de vista que as organizações sindicais tratadas (Contag e Fetraf) Ihe atribuem, enquanto identidade política e projeto de agricultura. Para maiores detalhes sobre os debates acerca da construção da categoria agricultura familiar no Brasil, ver Picolotto (2011; 2014a), Wanderley (2014), e sobre as disputas dessa categoria nas políticas públicas e em suas bases de agricultores, ver Bruno (2016) e Soldera \& Niederle (2016).

9. O Mutirão de Animação de Base foi um amplo conjunto de atividades realizadas com o objetivo de (re) construir a relação entre a direção e a base; inverter o processo de elaboração das pautas e preparação das lutas; "massificar" o projeto da CUT para o campo; construir uma metodologia diferenciada de formação (Aguiar, 1998).

\section{Dissidência no Sul e formação de um sindicalismo da agricultura familiar}

Neste processo de unificação do sindicalismo, algumas tensões emergiram e deflagraram dinâmicas diferenciadas nos estados. Na Região Sul, enquanto nos estados do Paraná e do Rio Grande do Sul os cutistas participaram das direções das Fetags em posições minoritárias, em Santa Catarina, após diversas tentativas frustradas de unificação, decidiram formar a Federação dos Trabalhadores na Agricultura Familiar de Santa Catarina (Fetrafesc), em 1997, como organização paralela à Federação reconhecida (Fetaesc). A Fetrafesc solicitou filiação à Contag, mas não foi aceita em nome da preservação da unicidade sindical. Com esta federação diferenciada, abria-se uma dissidência sindical no Sul, alimentada e fortalecida pelo reconhecimento que a categoria agricultura familiar passava a ter no âmbito das políticas públicas e no debate acadêmico ${ }^{8}$.

O processo de construção do agricultor familiar como personagem político na Região Sul contou com uma série de iniciativas do sindicalismo. A partir de 1996, começaram a ser construídas ações massivas de debate e organização dos agricultores familiares, como o Mutirão de Animação de Base ${ }^{9}$, realizado pelo Fórum Sul dos Rurais da CUT. Nos anos seguintes, foram organizadas mobilizações semelhantes nos municípios e realizados os Encontros da Agricultura Familiar da Região Sul. No encontro de 1999, em Francisco Beltrão (PR) - ocorrido após o VII Congresso da Contag, no qual a chapa apoiada pelos cutistas do Sul que defendia mudanças mais profundas na estrutura sindical foi derrotada -, foi tomada a decisão de construir a Frente Sul da Agricultura Familiar, organização para congregar diversos atores da agricultura familiar (organizações sindicais, cooperativas de crédito, leite e produção, associações e ONGs).

A Frente assumia como principal bandeira a busca de reconhecimento da agricultura familiar como personagem social, bem como de seu modelo de agricultura que, apesar de abranger um grande contingente da população ocupada e responsável por boa parte da produção agropecuária nacional, foi historicamente mantida em condições de invisibilidade socioeconômica frente às grandes fazendas de produção e os seus atores privados de representação. Com vistas a reverter esta condição de invisibilidade social, a Frente Sul passava a fazer uso da categoria agricultura familiar (em substituição a de pequeno produtor) como identidade coletiva e a ela passava a associar ideias positivas, tais como: produtora de alimentos, moderna, eficiente e sustentável. Esta positivação da agricultura familiar objetivava superar o imaginário de precariedade que existia em relação à pequena produção nas sociedades modernas, vista como um setor social atrasado, ineficiente e de desenvolvimento incompleto (Castilhos, 1999; Picolotto, 2011). 
A identidade coletiva de um movimento deve ser entendida, segundo Melucci (2001), como construção de significados, realizada no processo de formação do ator, interativa e compartilhada entre a complexidade interna de um ator e as suas relações com o ambiente social (outros atores, as oportunidades políticas e os vínculos que estabelece). Tendo essa perspectiva como parâmetro, pode-se afirmar que a Frente se apropriou da novidade que a categoria agricultura familiar representava em um cenário de acirradas disputas do campo sindical, consolidando a especificidade de um segmento de agricultores e construindo um projeto político de valorização deste modelo de agricultura. Colocava-se, assim, como possibilidade de proporcionar maior visibilidade para o movimento que não encontrava o espaço que almejava no sindicalismo sob a hegemonia da Contag.

O processo de fortalecimento da dinâmica organizativa e da identidade da agricultura familiar na Região Sul, aliado com a percepção das enormes dificuldades de mudança na correlação de forças nas Fetags da região e na Contag recolocava o debate sobre a possibilidade de formar uma estrutura sindical específica dos agricultores familiares na região. A fundação da Federação dos Trabalhadores na Agricultura Familiar da Região Sul (Fetraf-Sul) ocorreu durante o I Congresso Sindical da Agricultura Familiar, realizado entre os dias 28 e 30 de março de 2001, em Chapecó (SC). O congresso de fundação foi o ponto alto de um amplo processo de reflexão, mobilização e organização do sindicalismo identificado com a agricultura familiar na região (Fetraf-Sul, 2001).

Ademais, há ainda de se considerar outros aspectos do simbolismo político do congresso. Sua construção foi cuidadosamente arquitetada para garantir o respaldo político que a federação necessitava para se constituir enquanto ente sindical e organização cutista. Esse respaldo era importante, uma vez que se tratava de uma iniciativa ousada em relação ao que determinava a legislação sindical e em relação ao sistema Contag, ao espaço que ela ocupava na representação formal de todos os trabalhadores rurais do país, incluindo os agricultores familiares. Para apoiar a fundação da nova federação, estiveram presentes no congresso autoridades e lideranças políticas, tais como: João Felício, presidente nacional da CUT; Olívio Dutra, governador do Rio Grande do Sul; Lula, presidente de honra do Partido dos Trabalhadores (PT) e uma das maiores lideranças sindicais e populares do país, entre outras, que compartilhavam seu prestígio, seu "capital político" (Bourdieu, 2005).

As lideranças da CUT e do PT procuram emprestar seu capital político à criação da Fetraf-Sul, dando-Ihes reconhecimento e crédito como ente sindical:

Então se criou um clima, veio o Lula, ele ainda não era presidente, mas era provável candidato. A Fetraf, se não nasceu grande, nas- 
10. O Projeto

Terra Solidária foi implantado entre 1999 e 2000, com mais de três mil envolvidos nas regiões de atuação sindical rural cutista do Sul. Oportunizava a "formação de ensino fundamental vinculada à questão da agricultura familiar, profissionalizante e tal, mas com uma visão política de aposta na formação sindical" (Amadeu Bonato, Departamento de Estudos Socioeconômicos Rurais - Deser, entrevista 2010). ceu com muita força, apoiada por uma figura nacional que era o Lula, com uma dinâmica de base forte que era o Terra Solidária ${ }^{10} \mathrm{e}$ com um corpo sindical relativamente grande, contando com algo em torno de cento e tantos sindicatos de 200 ou 300 municípios. Então não era algo assim pequenininho. Então criou um susto em nível nacional e, sobretudo, com o debate que já estava ganhando corpo, que era essa ideia da agricultura familiar e que a Fetraf incorporou (Amadeu Bonato, Departamento de Estudos Socioeconômicos Rurais - Deser, entrevista ao autor, 2010).

Como se pode perceber, o conjunto de eventos e mobilizações e o apoio recebido de lideranças da CUT e do PT (além da falta de perspectiva de mudanças na correlação de forças no interior da Contag) teriam propiciado a "oportunidade política" (Tarrow, 2009) para que uma parcela do sindicalismo concretizasse o projeto de formar uma organização sindical de agricultores familiares na região. Para levar a cabo esse projeto, precisaram de força política para enfrentar as restrições da legislação sindical e do sistema sindical estabelecido.

\section{Debate na CUT sobre a criação de um novo ator: pluralismo cutista?}

A criação da Fetraf-Sul por um segmento cutista provocou reações da Contag, gerando um interessante debate sobre a estrutura sindical entre dois grupos concorrentes no campo: os "cutistas contaguianos" e os "cutistas pró-Fetraf". Em outubro de 2001, foi divulgado um texto assinado pela Direção Executiva da Contag (mas que depois seria contestado, sendo caracterizado como opinião de sua direção majoritária). Recebeu o título de "A filiação da Contag à CUT e a estratégia para o setor rural: um debate urgente e necessário" e expressou o descontentamento da confederação ante a criação da nova organização e o apoio que esta recebeu do presidente da CUT. O referido texto começa fazendo uma análise sobre o processo que levou a Contag a se filiar à CUT, e afirma que dentre as 26 federações estaduais, 15 estavam filiadas à CUT, em 2001, e que, desde 1998, todos os diretores da Contag eram cutistas. Com base nas resoluções do VII Congresso da CUT (Concut) de 2000, o texto argumenta que a central reconhecia os avanços obtidos no sindicalismo rural, porém, menos de um ano depois, a situação seria completamente diferente do que o estabelecido nas resoluções. Alguns setores cutistas estavam operando - "à revelia da direção da central, sem nenhuma discussão no conjunto da CUT, ou do ramo" (A filiação..., 2001: 3) - a construção de uma organização sindical paralela. No texto, são elencados vários elementos do processo de criação da Fetraf-Sul que, na ótica da direção majoritária da Contag, mereciam questionamentos por ferirem as resoluções políticas da CUT: a federação foi criada para abranger os estados do 
Sul, mas teve a participação de apenas 95 sindicatos em um universo de 875 STRs na região, o que lhe conferia pouca representatividade; no seu documento de fundação, existia a indicação de que ela nascia com a "perspectiva de contribuir para a consolidação de uma organização nacional que represente a Agricultura Familiar de todo o país" (A filiação..., 2001: 4), o que afrontava diretamente a Contag e prometia a concorrência com esta; era proposta a criação de um Fórum Nacional das Organizações da Agricultura Familiar para articular outros estados que também teriam sido "excluídos da estrutura e das instâncias da Contag" (A filiação..., 2001: 4); e era recomendado que os STRs deveriam declinar a filiação às Fetags.

Os autores do texto alegavam que essas afirmações

ignoram e se contrapõem à história de luta, desafios e conquistas da Contag e o seu reconhecimento como entidade representativa da agricultura familiar e do meio rural na CUT, conferido pelos delegados e delegadas do VII Concut (A filiação..., 2001: 4, grifos no original).

Afirmava ainda que ninguém havia sido excluído da estrutura ou das instâncias de decisão da Contag, o que ocorrera foi um processo de "autoexclusão" realizado por meio de repúdio à filiação de sindicatos e formação de uma estrutura paralela sem qualquer debate nas instâncias da Contag ou da CUT: "a estratégia de autoexclusão foi tomada isoladamente por um setor do ramo, no caso, os companheiros do extinto DNTR" (A filiação..., 2001: 4). Sobre a recusa dos pedidos de filiação das organizações diferenciadas (agricultores familiares e assalariados rurais), o texto reconhecia que esta proposta fora derrotada nos congressos da Contag, mas acrescentava que foram realizados debates amplos e democráticos sobre o tema, portanto, a decisão precisava ser acatada.

Passados poucos meses, outro grupo de dirigentes da Contag e da CUT (pró-Fetraf) divulgou um documento em resposta, apresentando argumentos que justificariam a criação de uma nova organização sindical da agricultura familiar. O texto divulgado em janeiro de 2002 recebeu o título de "Consolidar a implantação da CUT no meio rural: uma tarefa urgente e necessária"11. Começa fazendo um resgate sobre a trajetória do sindicalismo dos trabalhadores rurais para chegar às contribuições dos rurais da CUT para este setor do sindicalismo. Dentre essas são destacadas as deliberações tomadas na I Plenária do DNTR/CUT, de 1993, apontada como o ápice de um processo de reflexão vindo desde a década anterior, mas também como o momento da tomada da decisão de unificação com a Contag (decisão que não foi unânime e, segundo relatos dos entrevistados, recebeu voto contrário das lideranças do Sul).

\footnotetext{
11. Este texto

foi assinado por Francisco Miguel de Lucena (secretário de Formação e Organização Sindical da Contag), Airton Luiz Faleiro (secretário de Política Agrícola da Contag), Graça Amorim (secretária de Política Agrária e Meio Ambiente da Contag) Altemir Tortelli (secretário Nacional de Formação da CUT e suplente da direção da Contag), Luzia de Oliveira Fati e Elizângela Araújo (da Executiva Nacional da CUT)
} 
É destacado ainda que boa parte destas propostas cutistas foram incorporadas pela Contag (a exemplo do uso da categoria agricultura familiar, os Gritos da Terra e o Projeto Alternativo de Desenvolvimento Rural Sustentável), no entanto, as propostas de mudanças na estrutura sindical foram rejeitadas, "tanto nos espaços deliberativos da entidade, como na ação e nas políticas trabalhadas pela posição majoritária da direção" (A filiação..., 2001: 4). Neste aspecto, que parece ser o grande fator de discórdia, o texto ainda acrescenta que a CUT sempre defendeu o princípio de "liberdade e autonomia sindical"; que estudos feitos por "respeitadas ONGs e universidades brasileiras" e pelo Projeto CUT/Contag apontaram a "necessidade de radicais mudanças na organização sindical dos trabalhadores no campo" (A filiação..., 2001: 46) para melhor construir o Projeto Alternativo de Desenvolvimento Rural Sustentável.

A diversidade de experiências diferenciadas de organização no campo (mais de 200 entre organizações de base e estaduais, ver Projeto CUT/Contag, 1998) não poderia ficar sem uma organização coordenadora de âmbito nacional, uma vez que a Contag não aceitava a filiação dessas organizações. A mais antiga delas, a Feraesp, após vários pedidos de filiação negados pela Contag, decidiu filiar-se à Confederação Nacional da Alimentação (Contac). Nesse sentido, as federações de agricultores familiares que estavam surgindo - Fetrafesc, Federação da Agricultura Familiar de São Paulo (FAF-SP), criada em 1999, Fetraf-Sul e outras em processo de constituição - estariam fadadas a trilhar caminho próprio por falta de espaço na Contag.

Dos elementos destacados pelos textos, fica evidente que estava em disputa qual vertente sindical melhor representava o projeto da CUT no campo, a linha mais próxima de suas resoluções políticas, coerente com a sua trajetória. Mas, também fica claro que o principal fundamento da disputa dizia respeito ao formato da estrutura sindical a ser aplicado. Enquanto o grupo majoritário na Contag defendia a manutenção da estrutura corporativista e unitária e tentavam cobrar da CUT a conservação desta ordem, os dissidentes, valendo-se da opção programática da central pela liberdade e autonomia sindical justificavam a criação da Fetraf como caminho natural diante da resistência da Contag em aplicar o programa cutista.

\section{A Fetraf como estrutura orgânica da CUT}

A Fetraf surge como nova estrutura sindical de trabalhadores na agricultura familiar. A presença do termo trabalhadores em sua nomenclatura oficial sinaliza onde ela pretendia se posicionar no campo sindical. Em primeiro lugar, aponta sua intenção de estar ao lado das organizações de trabalhadores e em oposição às organizações patronais do campo - a exemplo da CNA e das federações patronais nos estados. Essa indicação é importante, uma vez que se trata de organização que representa 
pequenos proprietários que poderiam se posicionar tanto do lado dos trabalhadores como dos patrões. Trata-se de uma opção ideológica coerente com sua trajetória anterior. Em segundo lugar, pretendeu reforçar sua vinculação com a CUT, como central de trabalhadores. Essa vinculação direta com a central fez-se necessária devido ao fato de nascer em um campo onde já existia uma estrutura sindical estabelecida. A federação surgiu como estrutura orgânica da CUT, como federação cutista, integrante de sua estrutura vertical (Picolotto, 2011; 2014b).

A possibilidade de formar estas estruturas orgânicas esteve incluída em um amplo debate no âmbito da central sobre a forma de organização, debate que teve influência das experiências europeias (principalmente a italiana) e pela defesa do pluralismo sindical (Santos, 2003). Nesse sentido, a formação de uma "estrutura sindical cutista" por ramo funciona como

um organismo próprio à sua estrutura vertical interna, colocado em posição intermediária entre o sindicato de base e a direção nacional da central e que não tem ligação com a estrutura sindical oficial (Santos, 2003: 16).

Um exemplo característico foi o caso dos metalúrgicos da CUT que, por não terem o controle da organização nacional do ramo, formaram, em 1989, o Departamento Nacional dos Metalúrgicos que, posteriormente, em 1992, seria transformado na Confederação Nacional dos Metalúrgicos da CUT. No caso dos rurais, mesmo que o processo tenha sido mais complexo, a lógica é a mesma.

Como as estruturas sindicais orgânicas da CUT surgem em terrenos onde já existem outros atores estabelecidos, foi necessário traçar estratégias de diferenciação para poder afirmar sua própria identidade institucional, um programa político, uma base social, enfim, formas de justificar a sua criação. Como sugere Bourdieu: a "força das ideias na política" (Bourdieu, 2005: 185) mede-se pela força de mobilização que elas promovem, pela força do grupo que as reconhece. Neste sentido, "em política, 'dizer é fazer' [...] fazer crer que se pode fazer o que se diz" (Bourdieu, 2005: 185).

Considera-se que as federações cutistas, ao deflagrarem uma nova organização sindical, precisaram "fazer crer" que sua opção de organização era melhor do que a já existente, deflagrando um "novo grupo" no sindicalismo. Para isso, muitas vezes fizeram uso do empréstimo do capital político das lideranças da CUT e do PT, como ocorreu na fundação da Fetraf-Sul.

O trabalho político da Fetraf-Sul foi facilitado pela apropriação de uma categoria que já vinha sendo disseminada pelas políticas públicas (Pronaf), pela academia e que já 
estava sendo incorporada por boa parte do sindicalismo (Medeiros, 2014; Picolotto, 2014a). Na Região Sul, particularmente, já estava se construindo um movimento de afirmação desta categoria com identidade sociopolítica. Portanto, era um movimento político que estava amparado em uma ideia-força que já era bem aceita política e socialmente.

Para se diferenciar, a Fetraf-Sul procurou alicerçar seu desenho organizativo e sua forma de ação sindical em novas bases. A importância simbólica de romper com as regras do jogo então vigentes fica explícita na apresentação das resoluções do congresso de sua fundação:

Entre as principais resoluções está a criação da primeira Federação de Agricultores Familiares envolvendo três estados, numa clara demonstração de rompimento com a estrutura oficial corporativista e com a unicidade sindical (Fetraf-Sul, 2001: 5).

Isso se deu a partir da ruptura com a lógica de que as federações de segundo grau deveriam representar uma categoria de um estado e com a quebra da unicidade sindical, que determinava que só poderia existir uma estrutura sindical dos trabalhadores rurais (como categoria geral), representada oficialmente pelo sistema STR-Fetag-Contag.

Ao seguir essa perspectiva, a estrutura organizativa da Fetraf-Sul foi pensada a partir de uma coordenação geral no âmbito da Região Sul; de coordenações estaduais; de coordenações regionais (Sudoeste-PR, Oeste-SC e Alto Uruguai-RS); dos Sindicatos de Trabalhadores na Agricultura Familiar (Sintrafs) regionais ou coordenações sindicais microrregionais (microrregião Chapecó e microrregião Sarandi); de coordenações municipais dos sindicatos regionais (Fetraf-Sul, 2001). Este desenho organizativo foi pensado com vistas a "romper as regras" da estrutura sindical - tal como propugna -, mas também para, pragmaticamente, permitir que pudesse irromper no mundo sindical com importância política. Foi organizada como federação dos três estados do Sul, de um lado, por não possuir sindicatos suficientes em nenhum dos três estados para competir com as Fetags locais e, de outro, para obter maior projeção política nacional logo em seu nascimento. Em uma lógica similar, também se pode interpretar que os Sintrafs, por serem sindicatos regionais, distribuem a atuação sindical nos municípios e, com isso, conseguem acumular forças para competir com os STRs, que são estruturas consolidadas. São os instrumentos de base da Fetraf, fortalecidos por sua dimensão microrregional, por concentrarem a liderança e os recursos em um único aparato local.

Com a formação da Fetraf-Sul e de federações semelhantes em estados como São Paulo, Mato Grosso do Sul, Bahia e Minas Gerais consolidava-se a dissidência de 
uma parcela cutista da Contag. Na medida em que foram sendo iniciados movimentos de fundação de novas federações em outros estados, ganhava corpo a ideia de formar uma nova organização nacional da agricultura familiar. Em novembro de 2005, com a realização do I Congresso Nacional da Agricultura Familiar, em Luziânia (GO), foi fundada a Federação Nacional dos Trabalhadores na Agricultura Familiar (Fetraf-Brasil). No Congresso estavam presentes delegados de 22 estados, "reunindo aproximadamente 1.000 sindicatos, representando mais de 500 mil famílias de agricultores e agricultoras" (Fetraf-Brasil, 2005: 6). Era o momento de nacionalização da Fetraf.

\section{Campo sindical da agricultura familiar e a relação com o Estado nos governos petistas}

O surgimento da Fetraf, consonante com a opção da Contag por dar centralidade para a agricultura familiar, produziu uma situação de concorrência por bases sobre quem poderia falar em nome da categoria, sobre o uso da identidade da agricultura familiar, sobre o capital simbólico desta nova categoria e uma disputa no âmbito da legitimidade. Essa situação de concorrência tem possibilitado pôr em evidência duas formas de organização sindical distintas, mas que, em matéria de base social e programa político para a agricultura, pouco se distinguem.

Algumas das disputas travadas pelas organizações são reveladoras do que está em jogo nesse campo. A criação da Fetraf por dentro dos canais da CUT foi considerada uma afronta ao sistema sindical da Contag. Além de ir contra seus princípios de unicidade sindical, era outro agente cutista concorrendo com ela para falar em nome dos agricultores familiares. Contrariada com esta situação, solicitava providências à direção da CUT.

Essa disputa entre organizações causou um debate no interior da central sobre como deveria ser o seu modelo organizativo no campo e como equacionar os conflitos internos. Para amenizar a situação, a CUT adotou restrições quanto ao reconhecimento de Fetrafs e sindicatos nos locais onde já estavam atuando Fetags e sindicatos filiados à CUT. Estabeleceu as seguintes regras:

i. nos estados onde as Federações de Trabalhadores na Agricultura estiverem filiadas à CUT não serão reconhecidos e/ou filiados os Sintrafs e Fetrafs; e

ii. nos estados onde as federações estiverem filiadas a outras centrais, a CUT reconhece e filia as federações e sindicatos diferenciados de assalariados e agricultura familiar (CUT, 2009). 
Com essas regras, dava respaldo para a Fetraf se organizar nos estados em que as Fetags não eram filiadas à CUT (o que era o caso da Região Sul, sua principal base naquele momento), mas fechava a possibilidade de reconhecer sindicatos e federações que concorriam com organizações vinculadas à Contag e que também eram filiadas à CUT. Com isso, dava guarida tanto para a Fetraf como para a parcela cutista da Contag, solução que procurava conciliar os interesses dos grupos das duas organizações, cedendo um pouco para cada um. Mas, com essa determinação, criava empecilhos para o reconhecimento da Fetraf-Brasil, por esta atuar na mesma base da Contag.

Essa situação de concorrência intestina na CUT levou a insatisfações de setores da Contag e a questionamentos sobre a pertinência da filiação da Contag à CUT, uma vez que esta amparava organização concorrente. O ápice desse processo levou a desfiliação da Contag da CUT no Congresso de 2009. Decisão esta também influenciada pela fundação da Central dos Trabalhadores do Brasil (CTB), formada por dissidentes cutistas da Corrente Sindical Classista (CSC), ligada ao Partido Comunista do Brasil (PCdoB), da corrente Sindicalismo Socialista Brasileiro (SSB), próxima ao Partido Socialista Brasileiro (PSB), e sindicalistas independentes. A CTB assume a defesa da unicidade sindical como uma de suas principais bandeiras no tema da estrutura

FIGURA 1

DISTRIBUIÇÃO DAS FETAGS FILIADAS

À CUT E À CTB E PRESENÇA DE FETRAFS

computados 1.441 votos favoráveis a desfiliação da CUT e 1.109 contrários (Rodrigues \& Ladosky, 2015) sindical, o que a contrapõe à CUT, mas a aproxima de setores históricos da Contag (Medeiros, 2014; Galvão, Marcelino \& Trópia, 2015). Filiaram-se à CTB diversas federações de estados importantes, alterando, assim, o jogo de forças interno na Contag $^{12}$. A independência das centrais seria escolhida como o melhor caminho (Contag, 2009). Na Figura 1 pode-se observar a distribuição das Fetags que são filiadas à CUT e à CTB e a presença de Fetrafs nos estados.

Percebe-se a forte presença de Fetags filiadas à CTB nos estados do Sul, Sudeste e 
Centro-Oeste e nos estados da Bahia e Acre. A forte presença de Fetags filiadas à CUT nas regiões Nordeste e Norte e nos estados de Goiás e Espírito Santo, além do Distrito Federal. Por outro lado, a Fetraf está presente em todos os estados em que não existe Fetag filiada à CUT, com exceção do Rio de Janeiro e do Acre. Contudo, também se observa que a Fetraf mantém atuação em vários estados em que as Fetags são filiadas à CUT, principalmente em estados das regiões Nordeste e Norte, em Goiás e no Distrito Federal ${ }^{13}$. Essa presença da Fetraf em estados de Fetags cutistas evidencia a luta concorrencial que ocorre no interior da CUT.

Diante deste quadro de forte disputa entre vertentes sindicais percebe-se a conformação de um cenário de pluralismo sindical, com a concorrência entre diferentes atores pela representação da base social dos trabalhadores rurais e da agricultura familiar. Entretanto, quando se procura visualizar a forma da relação das organizações sindicais com o Estado, o modelo societário que tem se cristalizado está mais próximo de práticas neocorporativistas.

As duas organizações sindicais viveram boas relações com os governos Lula e Dilma, participando de alguns espaços em ministérios e galgando a conquista de importantes políticas públicas para as suas bases - crédito, garantia de preços da agricultura familiar, seguro agrícola, habitação rural, assistência técnica etc. (Grisa \& Schneider, 2014; Picolotto, 2014a). Esta relação com o Estado tem sido interpretada por alguns autores como "transformismo" do sindicalismo ou "cooptação" das organizações sindicais e dos movimentos sociais pelo Estado (Druck, 2006; Antunes, 2012; Antunes \& Silva, 2015; Soares, 2013). Tal proposta analítica não coteja adequadamente as suas boas relações ante os governos petistas com a trajetória histórica destas organizações (história de não reconhecimento e de exclusão) e com o fato de que elas também participaram do bloco no poder de forma consciente, ainda que subordinadas, com menor capacidade de interferir nas decisões importantes dos governos, mas que, mesmo assim, conquistaram políticas públicas e reconhecimento social para os setores subordinados do campo, em especial os agricultores familiares. Outros autores procuram associar esta situação com a ideia de "cogestão" das políticas públicas (Sabourin, 2017; Conti, 2016; Grisa \& Schneider, 2014; Bolter, 2013), ressaltando que ocorreu forte colaboração das organizações sindicais com os órgãos de Estado na gestão de recursos públicos e operacionalização de políticas. Mas, esta situação também pode ser relacionada, de forma mais ampla, com a conformação de relações baseadas no que se caracterizou como "neocorporativismo" ou, mais especificamente, com certo tipo de "estatização" da dinâmica social e das organizações sociais (Vianna, 2007; Ricci, 2013). Para este fenômeno, que Ricci (2013) chamou de "lulismo" (como forma de gestão do Estado conciliadora dos interesses das classes, uma tentativa de cons-
13. A Fetraf conta com 18 federações estaduais e indica que nos estados do Amazonas, Rio de Janeiro, Alagoas e Amapá está em "fase de consolidação" de sua estrutura organizativa. No ano de 2016, passou a se chamar ContrafBrasil (Contraf-Brasil, 2017). 
trução de unidade nacional), no âmbito do qual as organizações sindicais são convidadas a participar da composição do governo, bem como da elaboração e gestão das políticas públicas, mas para isso precisam integrar-se às arenas de negociação montadas pelo governo - como um "condomínio entre contrários" (Vianna, 2007) - em que as partes interessadas devem disputar, com base em seus argumentos e sua força política, a definição dos rumos da agenda nacional. Ao mesmo tempo em que o Estado abre estes espaços para participação das organizações da sociedade civil, possibilitando que estas exerçam sua influência na definição das agendas e decisões, atrai o foco e boa parte das lideranças e energias destas para o interior do Estado, conformando um "Estado de compromisso" (Vianna, 2007).

As organizações sindicais rurais - por terem atuado especialmente nos espaços do Ministério do Desenvolvimento Agrário (MDA) - conseguiram, por um lado, influenciar nas arenas a definição de importantes políticas públicas, mas, por outro, "se deixam estatizar" - no dizer de Viana (2007) -, abdicando de sua autonomia enquanto representante de grupos sociais específicos e de seus próprios projetos de desenvolvimento. Foram atraídas para a lógica do Estado, para a lógica pragmática do possível e do negociável. Renunciaram à característica mais pura e criativa dos movimentos sociais, às suas utopias e foram levadas a assumir o papel de executoras das políticas que ajudaram a construir. Ao assumirem esta lógica, tornaram-se parte interessada na continuidade do modelo societário neocorporativista, onde elas são parte central por concentrarem o poder da representação dos interesses dos agricultores familiares.

\section{Que pluralismo sindical é possível? Organizações ecléticas e específicas}

Outro campo de disputas entre as duas vertentes sindicais tem se desenhado no âmbito jurídico. Como a Fetraf-Sul não encontrou amparo legal para ser reconhecida como federação (de segundo grau) pelo Ministério do Trabalho, as Fetags da Região Sul questionam a sua legalidade e suas ações de representação sindical. No ano de 2003, as três federações do Sul deram entrada conjuntamente no Superior Tribunal de Justiça (STJ) com um pedido de Mandado de Segurança contra a inclusão da Fetraf-Sul e de seus sindicatos como organizações credenciadas pelo MDA para fornecer Declarações de Aptidão ao Pronaf (DAPs). As três federações alegavam que a área de atuação da Fetraf-Sul se sobrepunha às delas, o que feria a unicidade sindical, e ainda que a mesma não possuía Carta Sindical. Frente a este pedido, a ministra Denise Arruda, do STJ, ao analisar o mérito das acusações argumentou: 
profissional ou econômica na mesma base territorial, o inciso I do referido dispositivo constitucional dispõe que "a lei não poderá exigir autorização do Estado para a fundação de sindicato, ressalvado o registro no órgão competente, vedadas ao Poder Público a interferência e a intervenção na organização sindical". [...] Cumpre registrar que a supracitada entidade [Fetraf-Sul] foi devidamente constituída por meio de registro no Cartório [...] sendo mera formalidade a exigência do registro junto ao Ministério do Trabalho e Emprego (Arruda, 2004, grifos no original).

Da argumentação da juíza, depreendem-se a dubiedade na Constituição quanto ao regramento para a criação de novas organizações sindicais: mantêm a unicidade, ao mesmo tempo em que as organizações não precisam do reconhecimento do Estado para existir.

Nas diretrizes aprovadas pelo IX Congresso da Fetag-RS, no ano de 2007, consta a orientação de "processar a Fetraf-Sul por estar atuando ilegalmente" (Fetag-RS, 2007: 8). Em Santa Catarina, seguindo uma linha semelhante, a Fetaesc entrou com um processo na justiça "requerendo a nulidade da criação e a cessação da atividade como federação da Fetraf-Sul" (Fetaesc, 2008). Pelo fato de a Fetraf-Sul não ter a Carta Sindical, era denunciada como mera "ONG" e solicitava-se a suspensão de suas atividades sindicais.

Ao observar esses conflitos na Justiça como um campo de disputa, percebe-se que o ator estabelecido estava fazendo uso de recursos do campo jurídico para desqualificar e dificultar a atuação do ator desafiante que procurava se firmar no campo sindical. Contudo, o campo jurídico não é neutro e imutável na interpretação da legislação. Assim como outros campos, está sujeito a mudanças, motivadas ou não por pressões externas (Bourdieu 2005).

Ao dar continuidade à disputa jurídica, a Fetaesc ajuizou cobranças de contribuições sindicais que alegava devidas pelos agricultores familiares da base sindical da Fetraf-Sul por considerar-se a única representante sindical de âmbito estadual. Em reação a este ato, a Fetraf-Sul moveu uma ação contra as cobranças efetuadas pela Fetaesc. A sentença judicial sobre este caso é reveladora de como foi construído o entendimento jurídico para dar o reconhecimento à Fetraf-Sul como organização sindical legítima. A sentença da juíza Gisele P. Alexandrino (2008) baseia-se no princípio da liberdade e autonomia de organização sindical previsto na Constituição de 1988, recupera casos precedentes semelhantes e, por fim, declara que "não foi desrespeitado o princípio da unicidade sindical, uma vez que a federação ré [Fetaesc] é genérica e a federação-autora [Fetraf-Sul] é específica e exclusiva de uma classe" 
(Alexandrino, 2009: 14). Dava, assim, ganho de causa para a Fetraf, como credora das contribuições sindicais.

Essas decisões favoráveis à Fetraf-Sul deram-lhe certa segurança jurídica frente às investidas dos adversários. Consolidava-se, assim, sua posição no campo como representante específica dos agricultores familiares, enquanto as federações do sistema Contag seriam representantes ecléticas (genéricas) dos trabalhadores rurais em geral.

Uma das consequências destas disputas e dos rebatimentos no campo jurídico consolida o entendimento de que podem existir sindicatos específicos no interior de uma categoria eclética (como a de trabalhador rural), o que tem legitimado iniciativas de divisão de sindicatos ou criação de novos por outros atores concorrentes. No Rio Grande do Sul e em Santa Catarina, por exemplo, existem diversos sindicatos específicos de agricultores familiares da Fetraf, alguns destes surgiram nas bases de sindicatos contaguianos por dissociações (Picolotto, 2011; Conti, 2016).

Frente a esta situação de concorrência política e disputas judiciais, o Ministério do Trabalho e Emprego (MTE) criou, em 2013, o Grupo de Trabalho Rural em conjunto com as centrais e organizações sindicais da área (Contag, Fetraf e Feraesp) para

estudar a realidade das relações de trabalho dos trabalhadores no âmbito rural, objetivando construir consensos para apresentação de propostas que definam a sua representação sindical (Brasil, 2013).

Nos trabalhos do grupo foi consolidado o entendimento em favor de uma nova normativa que redefinia a categoria de enquadramento sindical trabalhador rural do Decreto-Lei $n$. 1.166 , de 1971, abrindo

a possibilidade de dissociação da categoria eclética de trabalhador rural nas categorias específicas de assalariados rurais e de agricultores familiares (Brasil, 2014, grifos nossos).

Ou seja, abria-se a possibilidade legal da existência de mais duas categorias específicas de sindicalização independentes. Passam a poder coexistir a categoria eclética existente de trabalhador rural, composta pelos assalariados rurais e os agricultores familiares e as novas categorias específicas: agricultor familiar e assalariado rural.

Atenta com esta possibilidade e visando não dar espaços para os atores concorrentes, o sistema sindical da Contag vem discutindo este tema desde o seu Congresso Nacional de 2013, quando foi sugerido o estabelecimento de uma regulamentação 
para os processos de dissociação de sindicatos (Contag, 2013). Ao perceber que estava perdendo bases para os adversários e que estes obtinham importantes vitórias pela via judicial, a Contag passou a orientar os seus sindicatos para fazerem um processo de "dissociação" de uma das categorias de representação sindical (agricultores familiares ou assalariados rurais) quando considerassem necessário, como declarou o presidente da Contag:

No nosso entendimento, a dissociação é o melhor caminho para preservar os nossos interesses, a nossa unidade e o conceito de categoria. A possibilidade de representar a agricultura familiar, o assalariado, sem tirar o direito dos sindicatos que querem permanecer juntos. E isso é um direito sagrado. As decisões judiciais afirmam que a dissociação de uma categoria (por exemplo, a de assalariados) de uma organização eclética (Sindicato de Trabalhadores Rurais) não fere a Unicidade Sindical, e por isso as duas podem existir na mesma base, prevalecendo a representação da entidade mais específica (Alberto Broch, Portal CTB, 2014).

Com esta nova orientação, a Contag está procurando adaptar-se ao novo cenário em que foi aberta claramente a possibilidade de existência de sindicatos mais específicos do que a categoria geral de trabalhador rural; tenta frear as dissidências políticas e a excessiva fragmentação de sindicatos (no próprio documento do seu XI Congresso Nacional, de 2013, são citados outros caso de categorias que pleiteiam a criação de sindicatos próprios, como os pescadores artesanais, quilombolas, ribeirinhos e extrativistas) e, ao mesmo tempo, busca preservar o seu papel de central camponesa, como foi conhecida em décadas anteriores.

Estas orientações têm provocado um processo de dissociação de sindicatos e de federações, desde 2014. Alguns passam a representar somente os agricultores familiares e outros assalariados. Como ápice desse processo, no dia 31 de outubro de 2015, foi fundada, em Brasília-DF, a Confederação Nacional dos Trabalhadores Assalariados Rurais (Contar), como organização sindical dos assalariados rurais. Com ela foi consolidado o processo de dissociação da categoria dos assalariados em escala nacional (conta com sete federações organizadas, presentes nos seguintes estados: Rio de Janeiro, Mato Grosso do Sul, Pará, Pernambuco, Goiás, Paraná e Rio Grande do Sul) e a Contag tem dado sinais de que pretende ser uma organização de agricultores familiares, ainda que não renuncie a representação eclética de todos os trabalhadores rurais (Contag, 2017). Contag e Contar afirmam que pretendem ser organizações próximas e colaborar em suas lutas.

Na prática, as possibilidades de dissociação de sindicatos específicos e de formação de novas organizações sindicais de nível superior (como a Fetraf, Feraesp e Contar) 
é a forma possível de existência de certo pluralismo sindical no país, mesmo diante de uma legislação restritiva, que estabelece a unicidade.

\section{Considerações finais}

Da reflexão realizada no trabalho, pode-se constatar que a estrutura sindical dos trabalhadores rurais existente não foi capaz de representar satisfatoriamente a diversidade de interesses e de grupos sociopolíticos no campo. Desde a década de 1980 emergiram diversos novos atores sociais questionando a forma corporativa de representação e construindo novos canais de organizativos, seja optando por constituir movimentos (como MST, MAB e, nos anos de 1990, o MPA) relativamente independes dos canais sindicais, seja formando novas estruturas sindicais (como DNTR, Feraesp e Fetraf).

Como resultado deste processo, criou-se uma situação em que mesmo mantido o discurso de defesa da unicidade sindical por parte da Contag, a realidade atual da representação do conjunto dos trabalhadores rurais (sejam eles agricultores familiares, sejam assalariados, sem-terra etc.) mostra uma situação de pluralidade de atores de representação. Cada ator representa um grupo ou uma categoria social e tem determinados alinhamentos políticos ou sindicais. Com esta nova condição de concorrência entre atores, foi enfraquecida a forma de representação corporativa tradicional do sindicalismo dos trabalhadores rurais e, por consequência, ocorreu certa perda de poder da organização estabelecida (quando comparada com as de épocas anteriores).

Mesmo que tenham ocorrido esforços - tanto por parte da CUT como da Contag para unificar o sindicalismo com vistas a sanar algumas das deficiências da representação deste setor, estes não foram suficientes para conciliar interesses e posições políticas diversas. Se, por um lado, a convergência de esforços entre a CUT e a Contag em alguns momentos teve a capacidade de produzir resultados considerados positivos pelas organizações em matéria de conquistas de políticas públicas e de elaboração programática do sindicalismo, por outro, as divergências sobre a estrutura sindical e as disputas de espaços de poder entre diferentes grupos levaram a formação de uma dissidência cutista no sul do país que deflagrou o processo de formação da Fetraf.

Como se apontou no texto, os cutista fizeram o possível para estar dentro da Contag, conquistar espaços no interior da estrutura sindical e ter acesso aos seus recursos financeiros e simbólicos, mas esbarraram na concorrência com outros grupos políticos e com a força da estrutural sindical estabelecida que limitaram as suas 
possibilidades de assumir a direção efetiva do movimento sindical de trabalhadores rurais. Ilustra bem isso as sucessivas recusas dos pedidos de filiação das organizações sindicais diferenciadas (específicas) criadas por cutistas entre agricultores familiares e assalariados rurais. Como estas organizações específicas já eram uma realidade em diversos locais, procuraram criar espaços próprios para sua atuação como entidades orgânicas da CUT.

Ao avançar nesta interpretação, as origens da Fetraf denotam certas incapacidades da estrutura sindical corporativa em absorver para a confederação (ente sindical superior no país) as novas organizações de agricultores familiares emergentes. Também contribuiu a defesa programática da CUT em favor da autonomia e liberdade sindical, o que estimulou a formação de novas organizações por grupos descontentes, ou que estavam fora das estruturas sindicais, e os atritos gerados com a direção majoritária da Contag. Todavia, como se demostrou no artigo, a formação da Fetraf no sul do país é também resultado de um conjunto de experiências organizativas próprias dos cutistas rurais que, desde a década de 1980, conheceram avanços e recuos na construção das "oposições sindicais", na formação da Articulação Sindical Sul, do DNTR e, posteriormente, do Fórum Sul dos Rurais da CUT, já no início dos anos 1990. Mas, acima de tudo, as possibilidades de formar uma organização sindical de agricultores familiares de âmbito regional passou pela construção de um movimento de valorização da agricultura familiar construído na segunda metade da década de 1990, com os Mutirões e Encontros Regionais da Agricultura Familiar, a formação da Fetrafesc e da Frente Sul da Agricultura Familiar. Passou pelo reconhecimento social dos agricultores familiares e pelo fortalecimento da identidade da agricultura familiar com as ações do sindicalismo, os trabalhos acadêmicos e as políticas públicas para este público. O conjunto destas experiências e o fortalecimento da agricultura familiar como identidade política conferiu a estrutura para a criação da Fetraf-Sul, no ano de 2001. Criação reforçada com a transferência do capital político da CUT, como central sindical, bem como de lideranças políticas importantes relacionadas com o meio sindical e com o PT.

Com o acirramento da concorrência entre os atores nos últimos tempos e os desdobramentos dos conflitos judiciais e as novas normativas do MTE consolida-se o entendimento favorável à existência e ao reconhecimento das organizações sindicais específicas dentro da categoria eclética de "trabalhador rural". Neste cenário, a situação da Contag, que sempre teve o monopólio formal da representação da categoria, tornou-se insegura. Continuar sendo uma organização de representação eclética, uma espécie de central sindical camponesa, não parece ser mais a melhor opção, tendo em vista que a Fetraf e a Feraesp podem adquirir o reconhecimento do MTE para representar as categorias específicas dos agricultores familiares e 
dos assalariados rurais respectivamente. Desde 2014, o sistema sindical da Contag vem realizando mudanças com vistas a se recolocar no campo, dissociando a categoria dos assalariados rurais, criando o sistema sindical da Contar e dando sinais de que pretende representar centralmente os agricultores familiares. Nesta nova condição, Contag e Contar estão batendo de frente com as organizações sindicais que já realizavam a representação específica destas categorias, como a Fetraf e a Feraesp.

Esta situação de organizações específicas concorrendo pelas mesmas bases e requerendo os registros junto ao MTE ainda está indefinida. Os seus desdobramentos definirão os rumos da representação sindical rural.

\section{Pluralism, neocorporatism and unionism of family farmers in Brazil}

Abstract: The present paper has as objective to analyze the process of formation of the Fetraf in the traditional area of work of the Contag and the situation of trade union plurality generated. The Brazilian rural unionism was created in the 1960s and since its formation coexisted with a tension between the various social groups that formed the rural worker category. It were framed categories of living labor, such as employees, small landowners, squatters, landless. Since the return of democracy this system of union representation was questioned with the formation of many new actors in the field. However, it was with the creation of Fetraf in 2001, as a specific body of family farmers who went on to form a situation of trade union pluralism in the field. This has generated strong competition for legitimacy and union bases.

Keywords: trade unionism, trade union pluralism, family farming, Fetraf.

\section{Referências}

A FILIAÇÃO da Contag à CUT e a estratégia para o setor rural: um debate urgente e necessário. Brasília, Out. 2001 (mimeo).

AGUIAR, Vilênia P. Mutirão da agricultura familiar. Projeto CUT/Contag de pesquisa e formação sindical. Série "Experiências", n. 8. Florianópolis: Escola Sul/CUT, 1998.

ALEXANDRINO, Gisele P. Acórdão - 3ạ T-RO 00363-2008-009-12-00-2. Florianópolis, 2009.

ALVES, Giovanni. Do "Novo sindicalismo" à "concertação social": ascensão (e crise) do sindicalismo no Brasil (1978-1998). Revista de Sociologia e Política, n. 15, 2000.

ANTUNES, Ricardo. A "engenharia da cooptação" e os sindicatos no Brasil recente. Correio da Cidadania, 17 Fev. 2012. 
ANTUNES, Ricardo; SILVA, Jair B. Para onde foram os sindicatos? Do sindicalismo de confronto ao sindicalismo negocial. Caderno CRH, v. 28, n. 75, Salvador, 2015.

ARAÚJO, Ângela; TÁPIAS, Jorge. Corporativismo e neocorporativismo: exame de duas trajetórias. Boletim Informativo e Bibliográfico de Ciências Sociais. n. 32, 1991.

ARRUDA, Denise. STJ - MS 9392/DF. Mandado de Segurança 2003/0212224-0. DJ 17 Dez. 2004, p. 390, Brasília, 2004.

BOBBIO, Norberto. Dicionário de política. 11. ed. Brasília: Editora UnB, 1998.

BOITO JR., A. O sindicalismo brasileiro nos anos 80. Rio de Janeiro: Paz e Terra, 1991.

BOLTER, Jairo A. G. Interfaces e cogestão nas políticas para agricultura familiar: uma análise do Programa Nacional de Habitação Rural. Tese (Doutorado em Desenvolvimento Rural)- PGDR/Universidade Federal do Rio Grande do Sul, Porto Alegre, 2013.

BOURDIEU, Pierre. O poder simbólico. 10 ed. Rio de Janeiro: Bertrand Brasil, 2005.

BRASIL - Ministério do Trabalho e Emprego (MTE). Nota Técnica n. 88. In: Manual de procedimentos de registro sindical. Brasília: MTE, 2014.

Portaria n. 005, de 10 de julho de 2013. Brasília: Diário Oficial da União, 2013.

BRUNO, Regina. Desigualdade, agronegócio, agricultura familiar no Brasil. Estudos Sociedade e Agricultura, v. 24, n. 1, p. 142-160, Abr. 2016.

CASTILHOS, Dino. A construção da identidade da agricultura familiar. Curitiba: Deser, 1999.

CENTRAL ÚNICA DOS TRABALHADORES (CUT). Resoluções do X Concut. São Paulo: CUT, 2009.

CENTRAL ÚNICA DOS TRABALHADORES (CUT); CONFEDERAÇÃO NACIONAL DOS TRABALHADORES DA AGRICULTURA (CONTAG). Desenvolvimento e sindicalismo rural no Brasil. Projeto CUT/Contag. Brasília: CUT/Contag, 1998.

CONFEDERAÇÃO NACIONAL DOS TRABALHADORES DA AGRICULTURA (CONTAG). Documento base e plano de lutas do XII Congresso Nacional dos Trabalhadores Rurais Agricultores e Agricultoras Familiares. Brasília: Contag, 2017.

- Documento Base do XI Congresso Nacional de Trabalhadores Rurais. Brasília: Contag, 2013. 
ـ Anais do X Congresso Nacional dos Trabalhadores Rurais. Brasília: Contag, 2009.

—. Anais do I Congresso Nacional Extraordinário dos Trabalhadores Rurais. Brasília: Contag, 1994.

CONFEDERAÇÃO NACIONAL DOS TRABALHADORES NA AGRICULTURA FAMILIAR (CONTRAF). Quem somos. Brasília: Contraf, 2017. Acessado em: 09 set 2017. Disponível em: <http://contrafbrasil.org.br/conteudo/1/quem-somos>.

CONSOLIDAR a Implantação da CUT no Meio Rural: uma tarefa urgente e necessária. São Paulo, Jan. 2002 (mimeo).

CONTI, Irio Luiz. Organizações sociais e políticas públicas: inserção da Fetraf-Sul nas políticas públicas de Segurança Alimentar e Nutricional. Tese (Doutorado), PGDR/ Universidade Federal do Rio Grande do Sul (UFRGS), Porto Alegre, 2016.

DEPARTAMENTO NACIONAL DOS TRABALHADORES RURAIS (DNTR). Resoluções do Il Congresso do Departamento Nacional dos Trabalhadores Rurais. São Paulo: DNTR, 1993a.

Resoluções da I Plenária Nacional. Praia Grande: DNTR, 1993b.

DOMINGUES, José Mauricio. Os movimentos sociais latino-americanos: características e potencialidades. Análise de Conjuntura Observatório Político Sul-Americano(Opsa), n. 2. Fev. 2007.

DRUCK, G. Os sindicatos, os movimentos sociais e o governo Lula: cooptação e resistência. Coleção "Osal”. Buenos Aires: Clacso, 2006.

FAVARETO, Arilson. S. Agricultores, trabalhadores: estudo sobre a representação sindical dos agricultores familiares brasileiros organizados na CUT. Dissertação (Mestrado em Sociologia) - Universidade Estadual de Campinas (Unicamp), Campinas, 2001.

FERNANDES, Bernardo M. Questões da Via Campesina. Presidente Prudente: Nera, 2004.

FEDERAÇÃO DOS TRABALHADORES E TRABALHADORAS RURAIS DO ESTADO DE SANTA CATARINA (FETAESC). Fetraf-Sul na mira da lei: Fetaesc requer ação declaratória de inexistência da Fetraf-Sul. Florianópolis: Fetaesc, 2008.

FEDERAÇÃO DOS TRABALHADORES NA AGRICULTURA NO RIO GRANDE DO SUL (FETAG-RS). Diretrizes aprovadas no IX Congresso Estadual dos Trabalhadores e das Trabalhadoras Rurais para o quadriênio 2008-2011. Porto Alegre: Fetag, 2007. 
FEDERAÇÃO NACIONAL DOS TRABALHADORES E TRABALHADORAS NA AGRICULTURA FAMILIAR (FETRAF-BRASIL). Resoluções do I Congresso Nacional da Agricultura Familiar. Brasília: Fetraf, 2005.

FEDERAÇÃO DOS TRABALHADORES E TRABALHADORAS NA AGRICULTURA FAMILIAR DA REGIÃO SUL (FETRAF-SUL). Resoluções do I Congresso Sindical da Agricultura Familiar. Chapecó: Fetraf, 2001.

GALVÃO, A.; MARCELINO, P.; TRÓPIA, P. V. As bases sociais das novas centrais sindicais brasileiras. Curitiba: Appris, 2015.

GOLDIN, Adrián. Corporativismo, neocorporativismo y libertad sindical. Derecho Laboral, v. 55, n. 247, 2013.

GÖRGEN, Frei Sérgio. A resistência dos pequenos gigantes: a luta e a organização dos pequenos agricultores. Petrópolis: Vozes, 1998.

GRISA, Catia; SCHNEIDER, Sergio. Três gerações de políticas públicas para a agricultura familiar e formas de interação entre sociedade e Estado no Brasil. Revista de Economia e Sociologia Rural, v. 52, supl. 1, p. 125-146, 2014.

HELLER DA SILVA, Osvaldo. A foice e a cruz: comunistas e católicos na história do sindicalismo dos trabalhadores rurais do Paraná. Curitiba: Rosa de Bassi Editora, 2006.

LADOSKY, Mario Henrique. A CUT e a questão corporativa no Brasil. Revista Ciências do Trabalho, n. 3, 2014.

MADURO, Acácia M. R. A prática sindical da Fetag (Federação dos Trabalhadores na Agricultura do Rio Grande do Sul). Dissertação (Mestrado) - Universidade Federal do Rio Grande do Sul (UFRGS), Porto Alegre, 1990.

MEDEIROS, Leonilde S. O sindicalismo rural nas últimas duas décadas: mudanças e permanências. In: OLIVEIRA, R. V. et alii (Orgs.). O sindicalismo na era Lula: paradoxos, perspectivas e olhares. Belo Horizonte: Fino Traço, 2014.

— Agricultura familiar no Brasil: aspectos da formação de uma categoria política. In: MANZANAL, Mabel; NEIMAN Guillermo (Orgs.). Las agriculturas familiares del Mercosur: trayectorias, amenazas y desafíos. Buenos Aires: Ciccus, 2010.

—. História dos movimentos sociais no campo. Rio de Janeiro: Fase, 1989.

MELUCCl, Alberto. A invenção do presente: movimentos sociais nas sociedades complexas. Petrópolis: Vozes, 2001. 
NOVAES, Regina. C. R. De corpo e alma: catolicismo, classes sociais e conflitos no campo. Rio de Janeiro: Graphia, 1997.

O'DONNELL, Guillermo. Acerca del "corporativismo" y la questión del Estado. Documento Cedeg G. E. Clacso, n. 2. Buenos Aires: Clacso, 1975.

OFFE, Claus. Atribuição de status público aos grupos de interesse. In: OFFE, Claus. Capitalismo desorganizado. São Paulo: Brasiliense, 1989.

PAIVA, V. Igreja e questão agrária. São Paulo: Loyola, 1985.

PALMEIRA, Moacir. A diversidade da luta no campo: luta camponesa e diferenciação do campesinato. In: PAIVA, V. (Org.). Igreja e questão agrária. São Paulo: Loyola, 1985.

PICOLOTTO, Everton L. Os atores da construção da categoria agricultura familiar no Brasil. Revista de Economia e Sociologia Rural, v. 52, p. 63-84, 2014a.

. A formação de um sindicalismo de agricultores familiares no Sul do Brasil. Sociologias, v. 16, n. 35, 2014b.

- As mãos que alimentam a nação: agricultura familiar, sindicalismo e política. Tese (Doutorado em Ciências Sociais) - Universidade Federal Rural do Rio de Janeiro (CPDA/UFRRJ), Rio de Janeiro, 2011.

PINTO, Luzia A. C. G. "A Contag de 64 a 76". In: ARAÚJO, Braz J (Org.). Reflexões sobre a agricultura Brasileira. Rio de Janeiro: Paz e Terra, 1979.

PORTAL CTB. Contag define estratégia de ação para o sindicalismo rural - entrevista com Alberto Broch, 19 Mar. 2014. Disponível em: <http://portalctb.org.br/site/ noticias-editorias/entrevistas-ctb/22082-contag-define-estrategia-de-organizacao-para-o-sindicalismo-rural.html>. Acessado em: 25 Abr. 2015.

REIS, Bruno P. W. Corporativismo, pluralismo e conflito distributivo no Brasil. Dados: Revista de Ciências Sociais, v. 38, n. 3, p. 417-457, 1995.

RICCI, Rudá. Lulismo: da era dos movimentos sociais à ascensão da nova classe média. Rio de Janeiro: Contraponto, 2013.

RODRIGUES, Iram J. O sindicalismo brasileiro: da confrontação à cooperação conflitiva. São Paulo em Perspectiva, v. 9, n. 3, p. 116-126, 1995.

RODRIGUES, I. J.; LADOSKY, Mario H. Paradoxos do sindicalismo brasileiro: a CUT e a ruralização da ação sindical. Lua Nova, n. 95, p. 87-142, 2015. 
SABOURIN, Eric. Origens, evolução e institucionalização da política de agricultura familiar no Brasil. In: BERGAMASCO, S. M. P.; DELGADO, G. Agricultura familiar brasileira: desafios e perspectivas de futuro. Brasília: MDA/Sead, 2017.

SANTOS, Tadeu R. dos. O atual debate no sindicalismo-CUT sobre organização sindical. Anais do XXVII Encontro Anual da Anpocs. Caxambu: Anpocs, 2003.

SCHMITTER, Phillippe. Still the century of corporatism? Review of Politics, n. 36, 1974.

SOARES, José de Lima. As centrais sindicais e o fenômeno do transformismo no governo Lula. Sociedade e Estado, v. 28 n. 3, 2013

SOLDERA, D.; NIEDERLE, P.; O meio do campo em disputa e as implicações da "nova" classe média rural na ação pública. Redes, v. 21, n. 3, p. 93- 116, Set./Dez. 2016.

TARROW, Sidney. O poder em movimento: movimentos sociais e confronto político. Petrópolis: Vozes, 2009.

VIANNA, Luiz Werneck. O Estado Novo do PT. Política Democrática, n. 18, 2007.

Liberalismo e sindicatos no Brasil. Rio de Janeiro: Paz e Terra, 1976.

VIEIRA, Flávia Braga. Dos proletários unidos à globalização da esperança: um estudo sobre internacionalismos e a Via Campesina. São Paulo: Alameda, 2011.

WANDERLEY, Maria N. B. O campesinato brasileiro: uma história de resistência. Revista de Economia e Sociologia Rural, v. 52, p. 25-44, 2014. 
